\title{
Margins! Margins. Margins? How Important Is Margin Status in Breast-Preserving Therapy?
}

\author{
Jürgen Dunst Kathrin Dellas \\ Universitätsklinikum Schleswig-Holstein, Campus Lübeck, Klinik für Strahlentherapie, Lübeck, Germany
}

\section{Keywords}

Breast cancer - Breast preservation - Margins .

Surgery · Radiotherapy

\section{Summary}

Margin status is surely a prognostic factor in patients undergoing breast-conserving therapy, but its impact is probably overestimated in case of adequate adjuvant radiotherapy. Radiotherapy improves local control after excision of the primary tumor in all subgroups of patients. There is, in contrast, no evidence that a certain margin width or a re-resection improves local control.

\section{Introduction}

Margin status has been an issue of controversial debates in the past years. The importance of clear margins after tumorectomy for breast cancer has been highlighted in large prospective trials already in the beginning of breast-conserving therapy $[1,2]$. In an early investigation from Boston, patients with negative, close, focally positive, and more than focally positive margins had local recurrence rates of $0 \%, 4 \%, 6 \%$ and $21 \%$ [2]. The assessment of margins has therefore been considered as a critical part of breast-preserving treatment, and a lot of progress has been made over the past years with regard to standardization of surgical procedures and pathological examination. This standardization is probably the most important factor for the significant reduction in local relapse rate from $1-2 \%$ per year in series of the 1980 s to an annual recurrence rate of $0.5-1 \%$ in recent years.

Although the general impact of margin status on local control is not under debate, there exists a broad variation between surgeons upon the definition of optimal and minimal

\author{
Schlüsselwörter \\ Brustkrebs · Brusterhaltung · Resektionsränder · \\ Operation · Radiotherapie
}

\section{Zusammenfassung}

Die pathohistologisch bestimmte Resektionsradikalität ist ein wichtiger prognostischer Faktor in der brusterhaltenden Therapie. Die Weite des freien Resektionsrandes hat allerdings bei adjuvanter Radiotherapie nur geringen Einfluss auf die Rezidivrate und die Bedeutung wird vermutlich überschätzt. Es gibt keinen Hinweis darauf, dass eine bestimmte Weite des freien Resektionsrandes nötig ist, und der Wert einer Nachresektion bei R0-Situation ist nicht belegt.

margin width, with the acceptance of smaller margins by more experienced surgeons [3]. Despite these uncertainties, measurement of margin width has been incorporated as a quality criterion in treatment guidelines for breast cancer [4]. The following article tries to define the role of margin status with emphasis on adjuvant radiotherapy, with the objective to optimize the combination of surgery and radiotherapy.

\section{Theoretical Considerations}

Tumor cells have the ability to invade the surrounding normal tissue. Isolated tumor cells or small foci of tumor cells are routinely found in the normal tissue around a tumor. These microscopic findings are even present in tumors that macroscopically appear to have a sharp border to the surrounding normal tissue. The well-known data from Holland demonstrate that the probability of finding tumor cells decreases with increasing distance from the macroscopic tumor $[5,6]$. These residual cells are considered as the source for a local

\section{KARGER}

Fax +497614520714

Information@Karger.de

www.karger.com

\section{(C) 2011 S. Karger GmbH, Freiburg}

$1661-3791 / 11 / 0065-0359 \$ 38.00 / 0$

Accessible online at:

www.karger.com/brc
Prof. Dr. med. J. Dunst

Universitätsklinikum Schleswig-Holstein

Campus Lübeck, Klinik für Strahlentherapie

Ratzeburger Allee 160, 23538 Lübeck, Germany

Tel. +49 451 500-6661, Fax -3324

Juergen.Dunst@uksh.de 
recurrence if left after tumorectomy. It is therefore likely that the risk for a local recurrence after surgery decreases with increasing margin width.

Radiotherapy can destroy tumor cells. The probability of local tumor control is a function of the number of clonogenic tumor cells, the radiosensitivity of these tumor cells, and the radiation dose. For a given radiosensitivity and a certain radiation dose, the chance of tumor control therefore depends on the amount of tumor cells in the target volume. If a standard dose of radiotherapy is prescribed, this dose should be to control a certain number of tumor cells on a microscopic level. If the initial surgery has already reduced the number of cells below this threshold, more surgery (e.g. a re-resection) with further reduction of tumor cells will not necessarily further increase local control.

There are several clinical data supporting these theoretical assumptions. Rudloff and coworkers found an in-breast tumor recurrence rate of $28 \%, 21 \%$, and $19 \%$ for lesions excised with margins of $<1 \mathrm{~mm}, 1-9 \mathrm{~mm}$, and $\geq 10 \mathrm{~mm}$, respectively, and risk reductions of $83 \%(\mathrm{p}=0.002), 70 \%(\mathrm{p}=0.05)$, and $24 \%(p=0.55)$ in these subgroups [7].

\section{Impact of Margin Status}

Margin status is surely a prognostic factor. Involved margins are associated with a significant increased risk of failure. This is especially true for patients treated with surgery alone, without adjuvant radiotherapy.

In patients undergoing radiotherapy, the impact of margin status is less clear. Various studies have demonstrated that involved margins are associated with an increased risk for local recurrence $[8,9]$. However, the hazard ratio is relatively low. Recent data from large studies and population-based registries suggest that the risk for a local recurrence is increased by a factor of 2 or less, which means that the impact of an $\mathrm{R} 1$ resection is comparable to or less than that of a radiation boost (tables 1 and 2) [10, 11]. In the large European Organisation for Research and Treatment of Cancer (EORTC) boost trial, margin status (free versus close versus involved) had no impact on the local recurrence rate [12].

\section{How Important Is Margin Width?}

Several guidelines for breast cancer treatment recommend a certain width of free margins, e.g. a free margin of $1 \mathrm{~mm}$ for the invasive tumor and $5 \mathrm{~mm}$ for the intraductal component in the current German guideline [13]. However, the impact of the margin width is probably overestimated [14]. A larger margin is associated with decreased failure risk, but the advantage decreases with increasing width and is small and mostly insignificant (table 3). On the basis of large data sets, an optimal margin width of about $2 \mathrm{~mm}$ has recently been recommended for ductal carcinoma in situ and invasive cancers in patients undergoing excision and adjuvant radiotherapy [8].

\section{Impact of Re-Resection}

Most guidelines recommend a re-resection in case of insufficient margin width in the pathological specimens [13]. However, there is no clear scientific basis for this recommendation. In particular, there are no prospective data - especially no data from randomized trials - that demonstrate a benefit of a re-resection in comparison to leaving the situation as it is. The impact of a positive margin status might suggest that changing an R1 status to an R0 status by a re-resection might improve local control. However, the prognostic impact must not necessarily result from the surgery but could be caused by different biological behavior, e.g. the more aggressive tumors are more likely to have an R1 resection. This would mean that an R1 resection is not a mechanistic problem but reflects a biological problem that cannot be solved by surgery alone. Nevertheless, a re-resection with the objective of achieving an $\mathrm{R} 0$ situation is justified due to the negative impact of an R1 status.

The situation is more difficult if the tumor has been completely removed with free margins in the initial excision. There are several arguments against a re-resection in these patients:

- In patients with an R0 resection, the difference in local failure rates between patients with close margins and patients with wider margins is small. In a retrospective investigation of 1,046 patients with close $(\leq 2 \mathrm{~mm}$ free margin) or positive margins after first excision, the local control was $95 \%$ in patients with no further excision and $94 \%$ in patients with re-excision; residual tumor was found in one-third of re-excision specimens, but this was correlated to other unfavorable prognostic factors such as an extensive intraductal carcinoma component (EIC) and node positivity [15].

- In case of a re-resection, residual tumor is found in the re-resection specimen in about $30 \%$ of patients, irrespective of where the re-resection has been performed [16].

- Multiple resections may increase the uncertainty for optimal definition of the target volume of the radiotherapy boost. As the boost has a clear impact, its quality and efficacy should not be decreased be a less important procedure.

\section{Impact of Radiotherapy and Impact of a Boost}

Radiotherapy can effectively reduce the risk of local recurrence. The large Early Breast Cancer Trialist' Collaborative Group (EBCTCG) meta-analysis has demonstrated that radiotherapy to the whole breast after breast-preserving surgery prevents 2 out of 3 recurrences [17]. An additional boost 
Table 1. Impact of margin status (R0 versus R1) and radiotherapy on local tumor recurrence in patients undergoing breast-conserving surgery

\begin{tabular}{|c|c|c|}
\hline & $\begin{array}{l}\text { Nodal-negative patients, } \\
\text { no systemic therapy }(\mathrm{n}=2232)\end{array}$ & $\begin{array}{l}\text { Nodal-positive patients } \\
\text { with systemic therapy }(\mathrm{n}=1250)\end{array}$ \\
\hline $\begin{array}{l}\text { Impact of } \mathrm{R} 1 \text { resection versus } \mathrm{R} 0 \text { resection on local recurrence rate, } \\
\text { hazard ratio }\end{array}$ & $1.93, p=0.01$ & $0.99, p=0.49$ \\
\hline $\begin{array}{l}\text { Impact of radiotherapy versus no radiotherapy on local recurrence rate, } \\
\text { hazard ratio }\end{array}$ & $4.13, \mathrm{p}<0.0001$ & $2.67, p=0.02$ \\
\hline
\end{tabular}

Table 2. Impact of margin status (R0 versus R1) on local tumor recurrence in patients undergoing breast-conserving surgery

\begin{tabular}{lll}
\hline & Local recurrence after 10 years & \\
\cline { 2 - 3 } & $\mathrm{pN0}(\mathrm{n}=461)$ & $\mathrm{pN}+(\mathrm{n}=312)$ \\
\hline R0 resection & $12 \%$ & $12 \%$ \\
R1 resection & $28 \%, \mathrm{p}<0.01$ & $18 \%$, n.s. \\
\hline
\end{tabular}

Besana-Ciani et al. 2008 [10].

$\mathrm{n} . \mathrm{s}=$ Not significant.

Table 3. Wider margins are not associated with significantly better local control after breast-conserving surgery for invasive breast cancer

\begin{tabular}{ll}
\hline & Impact on local tumor recurrence rate, hazard ratio (confidence interval) \\
\hline$>1 \mathrm{~mm}$ versus $\leq 1 \mathrm{~mm}$ & 0.69 (CI: 0.28-1.69), n.s. \\
$>2 \mathrm{~mm}$ versus $\leq 2 \mathrm{~mm}$ & 0.90 (CI: 0.44-1.84), n.s. \\
\hline Population-based analysis from Manitoba: Hardy et al. 2008 [21]. & \\
$\mathrm{CI}=$ Confidence interval, n.s. = not significant. & \\
\hline
\end{tabular}

Table 4. Summary on the impact of breast radiotherapy and a boost as compared to margin status on local recurrence rate after tumorectomy

\begin{tabular}{|c|c|c|c|}
\hline Parameter & & $\begin{array}{l}\text { Reduction of local recurrence rate, } \\
\text { hazard ratio }\end{array}$ & Significance \\
\hline Breast XRT & 45-50 Gy vs. no RT & $\sim 0.33$ & highly significant, LOE IA \\
\hline Margin involvement & R0 vs. R1 & $\sim 0.50-0.70$ & marginally significant, LOE II \\
\hline Margin width in case of free margins & close versus wide & $\sim 0.80-1.00$ & not significant, LOE II \\
\hline
\end{tabular}

with 10-16 Gy can further reduce the recurrence by a factor of about 2 [18]. Thus, radiotherapy is surely more important than the margin status. After complete tumor removal, radiotherapy is surely more important than additional surgical procedures (table 4). Moreover, radiotherapy can be delivered under defined quality criteria with high standards even on a nationwide basis $[18,19]$.

\section{Summary and Recommendations}

Optimal local control is a major goal in breast-preserving therapy. It increases not only the chance of breast preservation, but has an impact on overall survival at least in a subset of patients. Radiotherapy (whole breast irradiation plus a boost) is the most important procedure for improving local control after complete tumor excision. There is currently no evidence that re-resections or a certain margin width improve local control significantly or in a comparable manner as radiotherapy. Therefore, optimal delivering of radiotherapy should not be compromised in the multidisciplinary treatment of breast cancer.

\section{Disclosure Statement}

The authors have no conflict of interest to declare. 


\section{References}

1 Sauer R, Schauer A, Rauschecker HF, Schumacher M, Gatzemeier W, Sauerbrei W, Dunst J, Seegenschmiedt MH, Marx D: Breast preservation versus mastectomy in early breast cancer - 1991 update of the GBSG 1 - protocol and prognostic factors. The German Breast Cancer Study Group. Strahlenther Onkol 1992;168:191202.

2 Schnitt SJ, Abner A, Gelman R, Connolly JL, Recht A, Duda RB, Eberlein TJ, Mayzel K, Silver B, Harris JR: The relationship between microscopic margins of resection and the risk of local recurrence in patients with breast cancer treated with breast-conserving surgery and radiation therapy. Cancer 1994;74:1746-1751.

$\checkmark 3$ Azu M, Abrahamse P, Katz SJ, Jagsi R, Morrow M: What is an adequate margin for breast-conserving surgery? Surgeon attitudes and correlates. Ann Surg Oncol 2010;17:558-563.

4 Brucker SY, Wallwiener M, Kreienberg R, Jonat W, Beckmann MW, Bamberg M, Wallwiener D, Souchon R: Optimizing the quality of breast cancer care at certified German breast centers: a benchmarking analysis for 2003-2009 with a particular focus on the interdisciplinary specialty of radiation oncology. Strahlenther Onkol 2010;187:89-99.

$\checkmark 5$ Holland R, Veling SH, Mravunac M, et al.: Histologic multifocality of Tis, T1-2 breast carcinomas: Implications for clinical trials of breast-conserving surgery. Cancer 1985;56:979-990.

6 Holland R, Connolly JL, Gelman R, Mravunac M, Hendriks JH, Verbeek AL, Schnitt SJ, Silver B, Boyages J, Harris JR: The presence of an extensive intraductal component following a limited excision correlates with prominent residual disease in the remainder of the breast. J Clin Oncol 1990;8:113118.

7 Rudloff U, Brogi E, Reiner AS, Goldberg JI, Brockway JP, Wynveen CA, McCormick B, Patil S, Van Zee KJ: The influence of margin width and volume of disease near margin on benefit of radiation therapy for women with DCIS treated with breast-conserving therapy. Ann Surg 2010;251:583-591.
Dunne C, Burke JP, Morrow M, Kell MR: Effect of margin status on local recurrence after breast conservation and radiation therapy for ductal carcinoma in situ. J Clin Oncol 2009;27:1615-1620.

-9 Houssami N, Macaskill P, Marinovich ML, Dixon JM, Irwig L, Brennan ME, Solin LJ: Meta-analysis of the impact of surgical margins on local recurrence in women with early-stage invasive breast cancer treated with breast-conserving therapy. Eur J Cancer 2010;46:3219-3232.

10 Besana-Ciani I, Greenall MJ: The importance of margins status after breast conservative surgery and radiotherapy in node positive patients: a follow-up of 10-15 years. Int Semin Surg Oncol 2008;5:13.

11 Ewertz M, Kempel MM, Düring M, Jensen MB, Andersson M, Christiansen P, Kroman N, Rasmussen BB, Overgaard M: Breast conserving treatment in Denmark, 1989-1998. A nationwide population-based study of the Danish Breast Cancer Co-Operative Group. Acta Oncol 2008;47: 682-690.

12 Jones HA, Antonini N, Hart AA, Peterse JL, Horiot JC, Collin F, Poortmans PM, Oei SB, Collette L, Struikmans H, Van den Bogaert WF, Fourquet A, Jager JJ, Schinagl DA, WárlámRodenhuis CC, Bartelink H: Impact of pathological characteristics on local relapse after breastconserving therapy: a subgroup analysis of the EORTC boost versus no boost trial. J Clin Oncol 2009;27:4939-4947.

13 Kreienberg R, Kopp I, Albert U, et al.: Interdisziplinäre S3-Leitlinie für die Diagnostik, Therapie und Nachsorge des Mammakarzinoms. www.awmf.org/uploads/tx_szleitlinien/032-045_01. $p d f$.

14 Morrow M: Breast conservation and negative margins: how much is enough? Breast 2009;18 (suppl 3):S84-S86.

15 Chism DB, Freedman GM, Li T, Anderson PR: Re-excision of margins before breast radiation diagnostic or therapeutic? Int J Radiat Oncol Biol Phys 2006;65:1416-1421.
6 Swanson GP, Rynearson K, Symmonds R: Significance of margins of excision on breast cancer recurrence. Am J Clin Oncol 2002;25:438-441.

17 Clarke M, Collins R, Darby S, Davies C, Elphinstone P, Evans E, Godwin J, Gray R, Hicks C, James S, MacKinnon E, McGale P, McHugh T, Peto R, Taylor C, Wang Y; Early Breast Cancer Trialists' Collaborative Group (EBCTCG): Effects of radiotherapy and of differences in the extent of surgery for early breast cancer on local recurrence and 15-year survival: an overview of the randomised trials. Lancet 2005;366:2087-2106

18 Poortmans PM, Collette L, Horiot JC, Van den Bogaert WF, Fourquet A, Kuten A, Noordijk EM, Hoogenraad W, Mirimanoff RO, Pierart M, Van Limbergen E, Bartelink H; EORTC Radiation Oncology and Breast Cancer Groups: Impact of the boost dose of $10 \mathrm{~Gy}$ versus $26 \mathrm{~Gy}$ in patients with early stage breast cancer after a microscopically incomplete lumpectomy: 10-year results of the randomised EORTC boost trial. Radiother Oncol 2009;90:80-85.

19 Feyer P, Sautter-Bihl ML, Budach W, et al. DEGRO Practical Guidelines for palliative radiotherapy of breast cancer patients: brain metastases and leptomeningeal carcinomatosis. Strahlenther Onkol 2010;186:63-69.

20 Sautter-Bihl ML, Sedlmayer F, Budach W, Dunst J, Engenhart-Cabillic R, Fietkau R, Feyer P, Haase W, Harms W, Rödel C, Souchon R, Wenz F, Sauer R: Intraoperative radiotherapy as accelerated partial breast irradiation for early breast cancer: beware of one-stop shops? Strahlenther Onkol 2010;186:651-657.

21 Hardy K, Fradette K, Gheorghe R, Lucman L, Latosinsky S: The impact of margin status on local recurrence following breast conserving therapy for invasive carcinoma in Manitoba. J Surg Oncol 2008;98:399-402. 